\title{
Spatial variations of nitrogen trace gas emissions from tropical mountain forests in Nyungwe, Rwanda
}

\author{
N. Gharahi Ghehi ${ }^{1}$, C. Werner ${ }^{5}$, L. Cizungu Ntaboba ${ }^{1}$, J. J. Mbonigaba Muhinda ${ }^{2}$, E. Van Ranst ${ }^{3}$, \\ K. Butterbach-Bahl ${ }^{4}$, R. Kiese ${ }^{4}$, and P. Boeckx ${ }^{1}$ \\ ${ }^{1}$ Faculty of Bioscience Engineering, Isotope Bioscience Laboratory - ISOFYS, Ghent University, Belgium \\ ${ }^{2}$ National University of Rwanda (NUR), Department of Soil and Environmental Management (SEM), Rwanda \\ ${ }^{3}$ Department of Geology and Soil Science, Laboratory of Soil Science, Ghent University, Belgium \\ ${ }^{4}$ Karlsruhe Institute of Technology, Institute for Meteorology and Climate Research, Atmospheric Environmental Research, \\ Garmisch-Partenkirchen, Germany \\ ${ }^{5}$ Biodiversity and Climate Research Centre (BIK-F), Frankfurt, Germany
}

Correspondence to: N. Gharahi Ghehi (nasrin.gharahighehi@ugent.be)

Received: 19 October 2011 - Published in Biogeosciences Discuss.: 7 December 2011

Revised: 6 March 2012 - Accepted: 2 April 2012 - Published: 19 April 2012

\begin{abstract}
Globally, tropical forest soils represent the second largest source of $\mathrm{N}_{2} \mathrm{O}$ and $\mathrm{NO}$. However, there is still considerable uncertainty on the spatial variability and soil properties controlling $\mathrm{N}$ trace gas emission. Therefore, we carried out an incubation experiment with soils from 31 locations in the Nyungwe tropical mountain forest in southwestern Rwanda. All soils were incubated at three different moisture levels (50, 70 and $90 \%$ water filled pore space (WFPS)) at $17^{\circ} \mathrm{C}$. Nitrous oxide emission varied between 4.5 and $400 \mu \mathrm{g} \mathrm{N} \mathrm{m}^{-2} \mathrm{~h}^{-1}$, while NO emission varied from 6.6 to $265 \mu \mathrm{g} \mathrm{N} \mathrm{m}^{-2} \mathrm{~h}^{-1}$. Mean $\mathrm{N}_{2} \mathrm{O}$ emission at different moisture levels was $46.5 \pm 11.1$ (50\%WFPS), $71.7 \pm 11.5$ (70\%WFPS) and $98.8 \pm 16.4$ (90\%WFPS) $\mu \mathrm{g} \mathrm{N} \mathrm{m}^{-2} \mathrm{~h}^{-1}$, while mean NO emission was $69.3 \pm 9.3$ (50\%WFPS), $47.1 \pm 5.8$ (70\%WFPS) and $36.1 \pm 4.2$ (90\%WFPS) $\mu \mathrm{g} \mathrm{N} \mathrm{m}^{-2} \mathrm{~h}^{-1}$. The latter suggests that climate (i.e. dry vs. wet season) controls $\mathrm{N}_{2} \mathrm{O}$ and $\mathrm{NO}$ emissions. Positive correlations with soil carbon and nitrogen indicate a biological control over $\mathrm{N}_{2} \mathrm{O}$ and $\mathrm{NO}$ production. But interestingly $\mathrm{N}_{2} \mathrm{O}$ and $\mathrm{NO}$ emissions also showed a positive correlation with free iron and a negative correlation with soil $\mathrm{pH}$ (only $\mathrm{N}_{2} \mathrm{O}$ ). The latter suggest that chemodenitrification might, at least for $\mathrm{N}_{2} \mathrm{O}$, be an important production pathway. In conclusion improved understanding and process based modeling of $\mathrm{N}$ trace gas emission from tropical forests will benefit from spatially explicit trace gas emission estimates linked to basic soil property data and
\end{abstract}

differentiating between biological and chemical pathways for $\mathrm{N}$ trace gas formation.

\section{Introduction}

Nitrogen oxide emissions from soil are of major concern because of their significant impact on atmospheric chemistry and as a driver for global climate (Crutzen, 1979; WMO, 2006; Mosier et al., 1998; Breuer et al., 2000). Nitrous oxide $\left(\mathrm{N}_{2} \mathrm{O}\right)$ is one of the main contributors to radiative forcing and is becoming the main cause of stratospheric ozone destruction (Meehl et al., 2007). Nitric oxide (NO) acts as a catalyst in the synthesis of tropospheric ozone (Delmas et al., 1997; Holland and Lamerque, 1997) an important component in ecosystem and human health issues. Nitrous oxide and $\mathrm{NO}$ are produced in soils by microbial processes of nitrification, denitrification, nitrifier-denitrification (e.g. Davidson et al., 2000). Besides agricultural soils, tropical forest soils are considered as important sources for atmospheric $\mathrm{N}_{2} \mathrm{O}$ (Bouwman et al., 1993; Matson et al., 1990; Mosier et al., 1998; Breuer et al., 2000; Butterbach-Bahl et al., 2004; Kiese et al., 2003; Werner et al., 2006). Similarly, NO from tropical forest soils represents a significant source within the global atmospheric budget (Butterbach-Bahl et al., 2004; Gut et al., 2002). However, current estimates of global sources are still highly uncertain because detailed measurements, in 
particular, for tropical forest soils are scarce. Kroeze et al. (1999) and Mosier et al. (1998) estimated the contribution of $\mathrm{N}_{2} \mathrm{O}$ from tropical forest soils to be in the range of 2.2-3.7 $\mathrm{Tg} \mathrm{N}_{2} \mathrm{O}-\mathrm{N} \mathrm{yr}^{-1}$. The mean estimate of 3.0 $\mathrm{Tg} \mathrm{N}_{2} \mathrm{O}$ $\mathrm{N} \mathrm{yr}^{-1}$ accounts for about $18 \%$ of total $\mathrm{N}_{2} \mathrm{O}$ sources (Prather and Ehhaly, 2001). Werner et al. (2007a), using a GIS coupled mechanistic biogeochemical model (ForestDNDCtropica), provided a revised estimate of $1.34 \mathrm{Tg} \mathrm{N}_{2} \mathrm{O}-\mathrm{N} \mathrm{yr}^{-1}$ $\left(0.88-2.37 \mathrm{Tg} \mathrm{N}_{2} \mathrm{O}-\mathrm{N} \mathrm{yr}^{-1}\right)$.

On the basis of limited available field measurements, the global contribution of tropical forest soils to the global NO budget is estimated at $1.1 \mathrm{Tg} \mathrm{NO}-\mathrm{N} \mathrm{yr}^{-1}$ (Davidson and Kingerlee, 1997). However, a detailed study of ButterbachBahl et al. (2004) indicates that NO emission from tropical rain forest soils might be as high as $3 \mathrm{Tg}$ NO-N $\mathrm{yr}^{-1}$.

Further, simulation results, using an $\mathrm{N}$ isotopic coupled mechanistic biogeochemical model, show that total gaseous losses, including $\mathrm{N}_{2}$, from tropical rain forest soils in Hawaii contributed for $\sim 26-48 \%$ of total $\mathrm{N}$ losses from natural ecosystems (Bai and Houlton, 2009).

So far current research and policy programs for tropical forests mainly focus on $\mathrm{C}$ storage and emission (Stickler et al., 2009; Defries et al., 2010). Though, tropical forest ecosystems play an important role in the global $\mathrm{C}$ balance, also non- $\mathrm{CO}_{2}$ greenhouse gases contribute to the net greenhouse gas balance from tropical forest ecosystems. For this reason, $\mathrm{N}_{2} \mathrm{O}$ and $\mathrm{NO}$ emission inventories in tropical forest are required as an additional decision tool for sustainable forest management and closing global trace gas budgets.

Despite the importance of tropical rain forest soils as source of atmospheric $\mathrm{N}_{2} \mathrm{O}$ and $\mathrm{NO}$, there are only few datasets available (Serca et al., 1994; Breuer et al., 2000; Kiese et al., 2005; Butterbach-Bahl et al., 2004; Gut et al., 2002; Werner et al., 2007b). The majority of $\mathrm{N}_{2} \mathrm{O}$ measurements were conducted in the Amazon, Central America (e.g. Keller and Reiners, 1994; Verchot et al., 1999) and in tropical regions of Australia (e.g. Kiese et al., 2003; Butterbach-Bahl et al., 2004). The only datasets of $\mathrm{N}_{2} \mathrm{O}$ emissions from tropical rain forest soils of Africa was reported by Serca et al. (1994) and Werner et al. (2007b), who worked in the Mayombe forest in the DR Congo and the Kakamega forest in Kenya, respectively. Furthermore, most studies on NO were carried out in the Amazon (Gut et al., 2002) and Queensland, Australia (Butterbach-Bahl et al., 2004). To our knowledge except for Serca et al. (1994), no reports on soil NO emissions from African tropical forest soils are available to date, indicating a need for an improved data availability of $\mathrm{N}$-trace gas exchange for African forest soils in particular.

It is widely accepted that the magnitude of forest soil $\mathrm{N}_{2} \mathrm{O}$ and $\mathrm{NO}$ emissions is highly variable and strongly influenced by environmental conditions, like soil properties and soil moisture (e.g. Davidson, 1993; Breuer et al., 2000). Additionally, knowledge of how soil properties and changes in soil moisture regulate the emission of these $\mathrm{N}$ oxide gases is essential for realistic predicting soil-atmosphere $\mathrm{N}$ trace gas exchange. Even though variations in soil moisture are considered as the main driver of temporal variations in $\mathrm{N}$ oxide emissions, it does not explain observed spatial variations from site to regional scales. Based on current knowledge it is obvious that observed spatial variations in $\mathrm{N}$ trace gas emissions must be closely linked to variations in soil properties, though effects of soil properties on $\mathrm{N}$ trace gas emissions are largely unexplored in the tropics. So far, only a few studies are available where variations in soil properties have been explicitly linked to spatial variation of $\mathrm{N}_{2} \mathrm{O}$ and $\mathrm{NO}$ emissions from tropical soils (e.g. Breuer et al., 2000; Ishizuka et al., 2005; Keller et al., 2005; van Haren, 2010).

However, more detailed information on the linkage between soil properties and $\mathrm{N}$ oxide emissions are needed to better understand spatial variability of $\mathrm{N}$ trace gas emissions in tropical forest regions. Furthermore, this information may be used for improving the parameterization and for validating predictions of mechanistic biogeochemical model such as the ForestDNDC-tropica (Werner et al., 2007a), which have recently been used to estimate global $\mathrm{N}_{2} \mathrm{O}$ emissions from tropical rainforest soils.

In-situ N-trace gas fluxes for plot-based studies are usually derived with static $\left(\mathrm{N}_{2} \mathrm{O}\right)$ or dynamic (NO) chamber measurements (see e.g. Kiese and Butterbach-Bahl, 2002). However, for regional scale flux estimates this approach is not feasible (especially not for remote areas) since it concentrates measurements only on a few sites with limitations to cover all climatic, soil and vegetation characteristics of a given region. Soil incubation studies in the laboratory have the advantage to allow for measuring $\mathrm{N}$-trace gas emissions from a high number of samples, thereby allowing to covering regional variability of soils. Several previous studies reported $\mathrm{N}$-trace gas fluxes, which were derived from soil incubation experiments and which agreed well with field-derived fluxes determined via chambers (Gut et al., 1999; Otter et al., 1999; Ludwig et al., 2001, van Dijk et al., 2002).

In view of the fact that few results on $\mathrm{N}_{2} \mathrm{O}$ and $\mathrm{NO}$ fluxes from African tropical rain forest soils have been reported and the limited knowledge on their spatial variability and control factors, we present results of $\mathrm{N}_{2} \mathrm{O}$ and $\mathrm{NO}$ emissions from an incubation experiment using 31 different soil samples from the Nyungwe tropical mountain forest in southwestern Rwanda. Our aims were (a) to quantify the magnitude and spatial variability of soil $\mathrm{N}_{2} \mathrm{O}$ and $\mathrm{NO}$ emissions, and (b) to determine the importance of different soil properties for explaining $\mathrm{N}_{2} \mathrm{O}$ and $\mathrm{NO}$ emissions from this central African tropical mountain forest. 


\section{Methods}

\subsection{Site description and soil sampling}

The study was conducted in the Nyungwe National Park covering an area of about $1000 \mathrm{~km}^{2}$ of tropical mountain forest, located between $2^{\circ} 17^{\prime}-2^{\circ} 49^{\prime} \mathrm{S}$ and $29^{\circ} 03^{\prime}-29^{\circ} 29^{\prime} \mathrm{E}$ at altitudes of 1485-2925 m in southwestern Rwanda (Fig. 1). Nyungwe is one of the largest mountainous rainforest areas remaining in Africa. It divides the Nile and the Congo river basins. The soils have been developed mainly from schists, micaschists, quartzitic schists and granites (UGent/Minagri, 2000a, b, c, d). The eastern part of the forest, with an altitude exceeding $2000 \mathrm{~m}$, is dominated by micaschists, whereas the western area featuring lower altitudes $(<2000 \mathrm{~m})$ shows schists as dominant parent material. Figure 1 illustrates the difference in elevation and parent material from the western to eastern part of the forest.

The forest contains various ecosystems ranging from dense forest, bamboo groves to marshes, and contains approximately 1105 plant species, as well as high biodiversity of fauna. Many species are endemic for the area and the central African Highlands (Graham et al., 1995; Sun et al., 1996; Masozera and Alavalapati, 2004; Plumptre et al., 2007; Fischer and Killmann, 2008).

The average annual precipitation from 1974 to 1989 as measured by the seven weather stations located in the vicinity of the Nyungwe forest (Fig. 1a) is $1660 \mathrm{~mm}$ (ranging from 1308 to $2071 \mathrm{~mm}$ ). In the dry seasons (June to August) monthly precipitation is below $80 \mathrm{~mm}$ per month and generally above $130 \mathrm{~mm}$ during the other months. The average monthly minimum and maximum temperature is 11 and $23^{\circ} \mathrm{C}$, respectively. The average annual temperature was $17^{\circ} \mathrm{C}$, with small seasonal variations (monthly mean range: $17.0^{\circ} \mathrm{C}$ in June to $17.6^{\circ} \mathrm{C}$ in April) (Minagri and CTB/BTS, 1993a, b). Weather data was not available for more recent years, but an automatic climate station has been established inside the Nyungwe forest $\left(2^{\circ} 28^{\prime}-43.3^{\prime \prime} \mathrm{S}, 29^{\circ} 12^{\prime} 00^{\prime \prime} \mathrm{E}\right)$ on February 2007 (Fig. 1a). The average annual mean temperature and precipitation at this location is $14.7^{\circ} \mathrm{C}$ and $1706 \mathrm{~mm}$, respectively (Nsabimana, 2009).

Soil sampling in the Nyungwe forest has been performed during September 2009 at 31 different locations (Fig. 2) covering all major soil types and climate conditions in the region. Soil core samples were taken from 0 to $10 \mathrm{~cm}$ depth. The soil samples were composite samples consisting of 5 different subsamples per location, which were taken in an $\mathrm{X}$-shaped pattern (in each leg head and in the center of the $\mathrm{X})$ of two meters from each head with a length of $\sim 2.8 \mathrm{~m}$ for each leg. All soil samples were immediately air-dried to reduce microbial activity during transportation to laboratory facilities in Belgium.

Total soil $\mathrm{C}$ and $\mathrm{N}$ content were measured by an elemental analyzer coupled to an isotope ratio mass spectrometer (EA-IRMS) (20-20, SerCon, Crewe, UK). Soil texture was determined by the Andreasen pipette method by sieving (Allen, 1975). The $\mathrm{pH}$ was measured by suspending dried soil samples in water (1:10 soil/water) and a glass electrode. Free iron (Fe oxides outside the silicate lattices) was measured upon sodium dithionite extraction (Mehra and Jackson, 1960) and measured via optical emission spectrometer (Varian ICP-OES) (720 ES, Mulgrave VIC 3170, Australia).

\subsection{Laboratory experimental conditions for soil $\mathrm{N}_{2} \mathrm{O}$ and NO measurements}

After air-drying the soil was homogenized by sieving $(2 \mathrm{~mm}$ mesh size). The soil samples in two replicate were incubated in the laboratory in tubes of $2.6 \mathrm{~cm}$ diameter, $9 \mathrm{~cm}$ height and $47.78 \mathrm{~cm}^{3}$ volume. The mass of dry soil needed was calculated from the measured field bulk density $\left(\rho_{b}\right)$ with the known volume ( $\left.\rho_{b}=\frac{\text { mass of dry soil }}{47.78 \mathrm{~cm}^{3}}\right)$. The soil moisture content was brought to three levels (50, 70 and $90 \%$ ) of waterfilled pore space (WFPS) and kept constant during the incubation. The lowest water content in this study was $50 \%$, which is e.g. equivalent to lowest WFPS for Kakamega forest soils in Kenya ( $\sim 40 \%$ WFPS with daily precipitation only by $<5 \mathrm{~mm}$ ) (Werner et al., 2007b). The air temperature during the incubation was kept constant at $17^{\circ} \mathrm{C}$. To avoid that flux measurements are biased by the exponential increase of microbial activity upon remoistening the soil samples, all the soil incubation tubes were first pre-incubated at the three moisture levels at $17^{\circ} \mathrm{C}$ for 7 days.

\subsection{Measurements of soil $\mathrm{N}_{2} \mathrm{O}$ and NO production}

The incubation tubes were placed into airtight sealed glass containers with a volume of $1200 \mathrm{ml}$. Measurements of N oxide gases were performed at day 1, 3 and 5 upon 7 days pre-incubation. The headspace concentration of $\mathrm{NO}$ of each incubation tube sample was measured four times $(0,40,80$ and 120 min after closing the glass containers) during each measuring day.

NO concentration of the headspace was determined using a NO analyzer (CLD 77AM, Eco Physics, Switzerland) with a continuous flow rate of $55 \mathrm{ml} \mathrm{min}^{-1}$. The detection is based on the chemoluminescence of the oxidation of $\mathrm{NO}$ to $\mathrm{NO}_{2}$ in the presence of ozone $\left(\mathrm{O}_{3}\right)$.

The NO analyzer was calibrated using an NO reference gas, with a known concentration of $9.8 \mathrm{ppmv} \pm 0.5$ in $\mathrm{N}_{2}$. Following measuring NO concentrations at $0,40,80$ and $120 \mathrm{~min}$, the same containers were used to sample $\mathrm{N}_{2} \mathrm{O}$ gas. Immediately after the NO measurements, $12 \mathrm{ml}$ gas sample was withdrawn from the headspace by a syringe. The gas sample was transferred to a $12 \mathrm{ml}$ vacutainer tube and stored for later measurements of $\mathrm{N}_{2} \mathrm{O}$ concentration. Since less than $10 \%$ of the headspace was used during the measurement the effect of change in pressure has been ignored in view of the large variability of observed $\mathrm{NO}$ and $\mathrm{N}_{2} \mathrm{O}$ fluxes. 


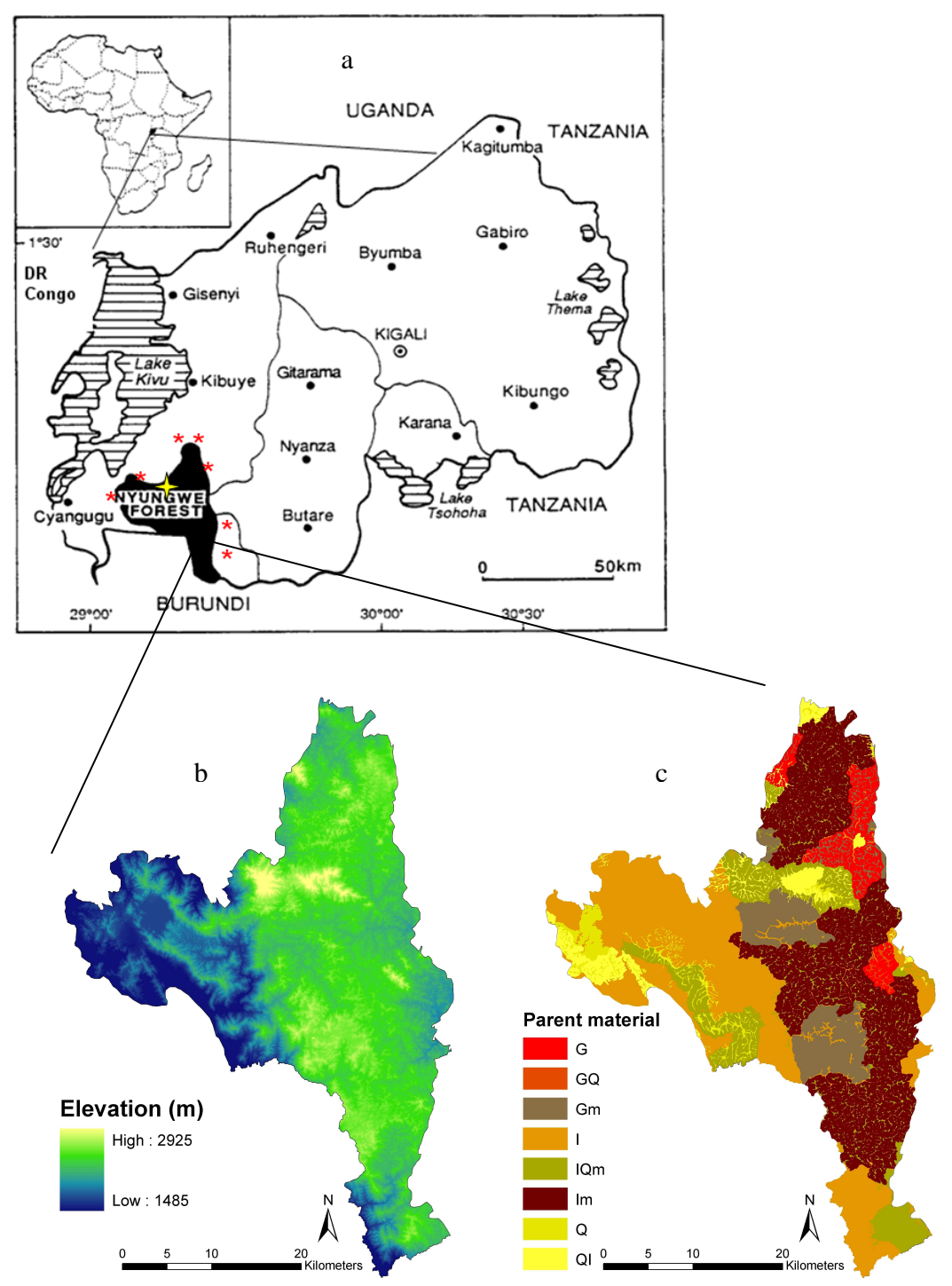

Fig. 1. Location of the Nyungwe forest in southwestern Rwanda; seven climate stations around the forest are shown by red stars; the recent climate station in the Nyungwe forest is shown by a yellow star (a), elevation map (b) and parent material map of the Nyungwe forest: $\mathrm{Q}=$ quartzite; $\mathrm{QI}=$ quartzite intercalated with schists; IQm = quartzite intercalated with micaschists; GQ = granitic and quartzitic rocks; $\mathrm{G}=$ acid rocks (granite); $\mathrm{Gm}=$ micaceous acid rocks (granitoide); $\mathrm{Im}=$ micaschists; $\mathrm{I}=$ schists $(\mathbf{c})$.

As a check on the reliability of NO measurements at each moment in time containers with known initial NO concentrations $(24.5,49.8$ and $99.7 \mathrm{ppb})$ were measured during the experiment to determine the leakiness of the glass containers, and the soil measurements were corrected accordingly with a correction magnitude of less than ca. $13 \%$. The $\mathrm{N}_{2} \mathrm{O}$ concentration was determined via a Gas Chromatograph (14B, Shimadzu, Japan) equipped with an electron capture detector ECD). One $\mathrm{ml}$ from the $12 \mathrm{ml}$ vacutainer was injected into the GC with a Hamilton airtight syringe. The GC analysis of the samples was always accompanied by measurements of varying amounts of a reference gas with a known concentration of $2.46 \pm 0.12 \mathrm{pmv}$ in order to construct a calibration curve for $\mathrm{N}_{2} \mathrm{O}$.

The ideal gas law in combination with the molecular weight of $\mathrm{N}_{2} \mathrm{O}$ and $\mathrm{NO}$ was used to calculate headspace gas concentrations in $\mu \mathrm{gl}^{-1}$. Those values were then converted to gas fluxes $\left(\mu \mathrm{g} \mathrm{kg}^{-1}\right.$ dry soil $\left.\mathrm{h}^{-1}\right)$ by multiplying with the headspace of the incubation jar, dividing with the amount of soil used and linear regression of changing headspace concentrations over time. The $\mathrm{NO}$ and $\mathrm{N}_{2} \mathrm{O}$ fluxes were finally recalculated to $\mu \mathrm{g} \mathrm{m}^{-2} \mathrm{~h}^{-1}$ using a known exposed soil surface area. 

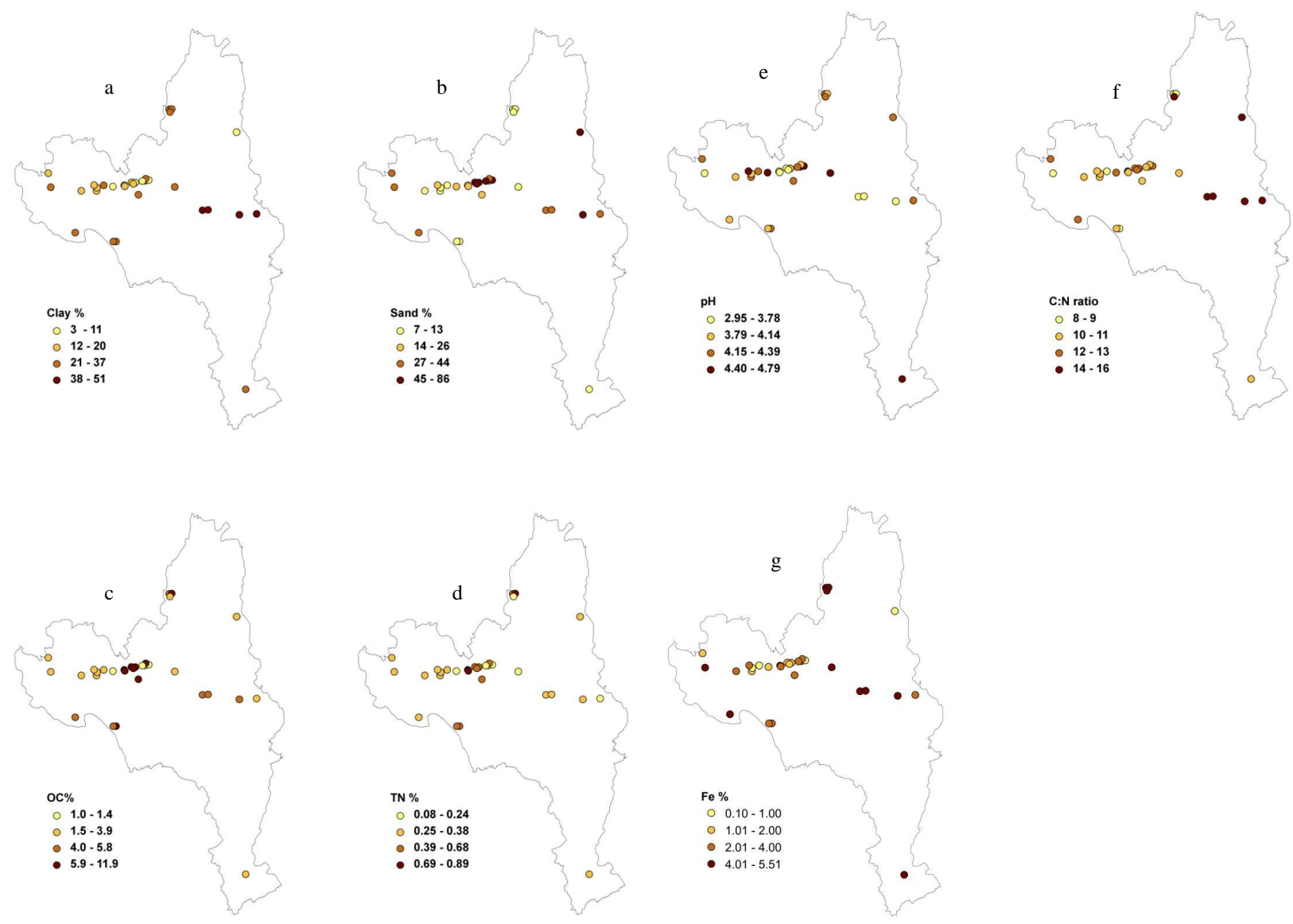

Fig. 2. Spatial pattern of the soil characteristics of the samples sites in the Nyungwe forest: clay (a), sand (b), organic carbon (OC) (c), total nitrogen $(\mathrm{TN})(\mathbf{d}), \mathrm{pH}(\mathbf{e}), \mathrm{C}: \mathrm{N}$ ratio $(\mathbf{f})$, free iron $(\mathrm{Fe})(\mathbf{g})$.

\subsection{Statistical analysis}

Statistical analysis was performed using the statistical package SPSS 16 (SPSS inc., 2007). Using the KolmogorovSmirnov goodness-of-fit test, each $\mathrm{N}$ oxide gas emission rate showed a log-normal distribution. Therefore, logtransformed data were used to make comparisons between groups and all data were tested at the $5 \%$ significance level. All data given in tables and figures are accompanied by the standard error (error bars).

\section{Results}

\section{1 $\mathrm{N}_{2} \mathrm{O}$ and NO production rates}

All $\mathrm{N}_{2} \mathrm{O}$ and $\mathrm{NO}$ fluxes showed significant effects for soil moisture. Multiple comparisons of all $\mathrm{N}_{2} \mathrm{O}$ fluxes (logtransformed data) from all sites showed a significant difference (Table 1) between the three applied WFPS levels. In all cases the highest fluxes were observed for $90 \%$ WFPS. A significant positive correlation was observed between $\mathrm{N}_{2} \mathrm{O}$ fluxes and WFPS for the entire dataset (Fig. 3). The $\mathrm{N}_{2} \mathrm{O}$ emission rate averaged over the 31 locations for day 1 , day 3 and day 5 were $40.2,43.2$ and $56.3 \mu \mathrm{g} \mathrm{N} \mathrm{m}^{-2} \mathrm{~h}^{-1}$, respectively for $50 \%$ WFPS, 70.7, 70.9 and $73.6 \mu \mathrm{g} \mathrm{N} \mathrm{m}^{-2} \mathrm{~h}^{-1}$ for $70 \%$ WFPS and 88.3, 109.6 and $98.3 \mu \mathrm{g} \mathrm{N} \mathrm{m}^{-2} \mathrm{~h}^{-1}$ for $90 \%$ WFPS (Table 1). In contrast to $\mathrm{N}_{2} \mathrm{O}$ emissions, $\mathrm{NO}$ emissions decreased with increasing soil moisture, with significant differences between the three applied WFPS levels. Consequently, the NO emission rates were significantly negatively correlated with WFPS (Fig. 3). The mean NO emission rate for day 1 , day 3 and day5 were 59.9, 61.3 and $86.6 \mu \mathrm{g} \mathrm{m}^{-2} \mathrm{~h}^{-1}$, respectively for $50 \%$ WFPS, $40.3,43.3$ and $57.6 \mu \mathrm{g} \mathrm{N} \mathrm{m}^{-2} \mathrm{~h}^{-1}$ for $70 \%$ WFPS and $33.9,33.3$ and $41.0 \mu \mathrm{g} \mathrm{m}^{-2} \mathrm{~h}^{-1}$ for $90 \%$ WFPS (Table 1 ).

\subsection{Variation of soil properties and $\mathrm{N}_{2} \mathrm{O}$ and $\mathrm{NO}$ gas emission rates}

The soil textural classes at the sampled sites were classified (USDA classification system) as clay (C), clay loam (CL), sandy loam (SL), silt loam (SiL), loamy sand (LS), silty clay $(\mathrm{SiC})$ and silty clay loam (SiCL). Table 1 and Fig. 2 show summary statistics and distribution for soil characteristics 
Table 1. Range, median, mean, standard error (SE), skewness and kurtosis of soil characteristics ${ }^{a}, \mathrm{~N}_{2} \mathrm{O}$ and NO flux rates (measured at day 1,3 , and 5 after pre-incubation). The letters indicate significant differences $(P<0.05)$ for mean $\mathrm{N}$ trace gas fluxes between different water-field pore space (WFPS).

\begin{tabular}{|c|c|c|c|c|c|c|c|}
\hline & & Range & Median & Mean & SE & Skewness & Kurtosis \\
\hline $\mathbf{N}_{2} \mathbf{O}\left(\mu \mathbf{g} \mathbf{N} \mathbf{m}^{-2} \mathbf{h}^{-1}\right)$ & & 31 & & & & & \\
\hline \multirow[t]{2}{*}{ WFPS $50 \%$} & Day 1 & $5.8-226.6$ & 21.5 & 40.2 & 10.4 & 2.5 & 5.7 \\
\hline & Day 5 & $7.7-244.2$ & 34.1 & 56.3 & 12.7 & 1.9 & 2.5 \\
\hline \multirow[t]{2}{*}{ WFPS $70 \%$} & Day 1 & $38.2-297.5$ & 46.7 & 70.7 & 11.7 & 2.5 & 5.6 \\
\hline & Day 3 & $31.1-245.9$ & 51.2 & 70.9 & 11.1 & 1.9 & 2.5 \\
\hline \multirow[t]{3}{*}{ WFPS $90 \%$} & Day 1 & $45.5-400.5$ & 55.6 & 88.3 & 16.4 & 2.9 & 8.2 \\
\hline & Day 3 & $41.0-400.5$ & 81.8 & 109.6 & 17.0 & 2.3 & 4.7 \\
\hline & Day 5 & $31.8-400.0$ & 80.3 & 98.3 & 17.0 & 2.2 & 4.2 \\
\hline \multicolumn{8}{|l|}{ average $1 \mathrm{st}, 3 \mathrm{rd}, 5$ th $d a y$} \\
\hline WFPS $50 \%$ & $\mathrm{CV}^{b} 133.3$ & $8.8-238.4$ & 23.6 & $46.5 \mathbf{a}$ & 11.1 & 2.1 & 3.2 \\
\hline \multirow[t]{3}{*}{ WFPS $50 \%$} & Day 1 & $0.7-260.8$ & 55.7 & 59.9 & 8.2 & 2.8 & 12.1 \\
\hline & Day 3 & $0.8-231.1$ & 52.1 & 61.3 & 7.9 & 1.9 & 6.2 \\
\hline & Day 5 & $2.6-265.5$ & 64.5 & 86.4 & 13.5 & 1.2 & 0.3 \\
\hline \multirow[t]{3}{*}{ WFPS $70 \%$} & Day 1 & $2.6-118.6$ & 33.4 & 40.3 & 5.1 & 1.2 & 1.0 \\
\hline & Day 3 & $4.3-113.7$ & 36.2 & 43.3 & 5.1 & 0.99 & 0.4 \\
\hline & Day 5 & $2.3-173.5$ & 46.0 & 57.6 & 8.1 & 1.3 & 1.3 \\
\hline \multirow[t]{3}{*}{ WFPS $90 \%$} & Day 1 & $3.4-127.5$ & 28.8 & 33.9 & 4.7 & 1.9 & 4.9 \\
\hline & Day 3 & $2.8-72.1$ & 28.7 & 33.3 & 3.0 & 0.6 & -0.2 \\
\hline & Day 5 & $0.9-144.5$ & 41.4 & 41.0 & 5.7 & 1.7 & 4.1 \\
\hline TN (\%) & CV 51.8 & $0.08-0.89$ & 0.35 & 0.4 & 0.4 & 0.6 & -0.2 \\
\hline $\mathrm{C}: \mathrm{N}$ & CV 11.2 & $7.7-16.3$ & 11.1 & 11.5 & 0.4 & 0.4 & -0.5 \\
\hline $\mathrm{pH}$ & CV 9.1 & $2.9-4.89$ & 4.2 & 4.1 & 0.6 & -0.92 & 0.82 \\
\hline $\mathrm{Fe}(\%)$ & CV 52.1 & $0.1-5.5$ & 3.04 & 3.03 & 0.3 & -0.24 & -1.02 \\
\hline
\end{tabular}

${ }^{\mathrm{a}} \mathrm{OC}=$ organic carbon, $\mathrm{TN}=$ total nitrogen, $\mathrm{C}: \mathrm{N}=$ organic carbon to total $\mathrm{N}$ ratio, $\mathrm{Fe}=$ free iron $(\mathrm{Fe}$ oxides from outside the silicate lattices)

${ }^{\mathrm{b}} \mathrm{CV}=$ coefficient of variation in $\%$

of the studied sites. The sites in the eastern and northeastern corners of the forest (Fig. 2a) showed high clay content ( $>37 \%$ ). The highest silt contents were found at sites in the northern part of the forest with values above $50 \%$. The sites in the northwestern corners had a very low fraction of sand $(<14 \%)$. The forest is dominated by strongly leached acid soils (pH ranging from 2.9 to 4.8). Areas with high soil organic carbon (OC) contents ( $>4 \%$, Fig. 2e), corresponding with high total nitrogen (TN) contents, were found in the northern and northeastern parts of the forest. OC content were in general high and ranged from 3.6 to $11.9 \%$, total $\mathrm{N}$ contents ranged from 0.08 to $0.89 \%$ and $\mathrm{C}: \mathrm{N}$ ratio ranged from 7.7 to 16.3 in the analyzed samples. Free iron ranged from 0.1 to $5.5 \%$ and high free iron contents $(>3 \%$, Fig. $2 \mathrm{~g}$ ) were mostly present in sites of the eastern part of the forest, where altitude is higher and micaschists dominate the soilscape (Fig. 1). The variation in silt, sand, clay content and free iron (formed through weathering) reflects the 

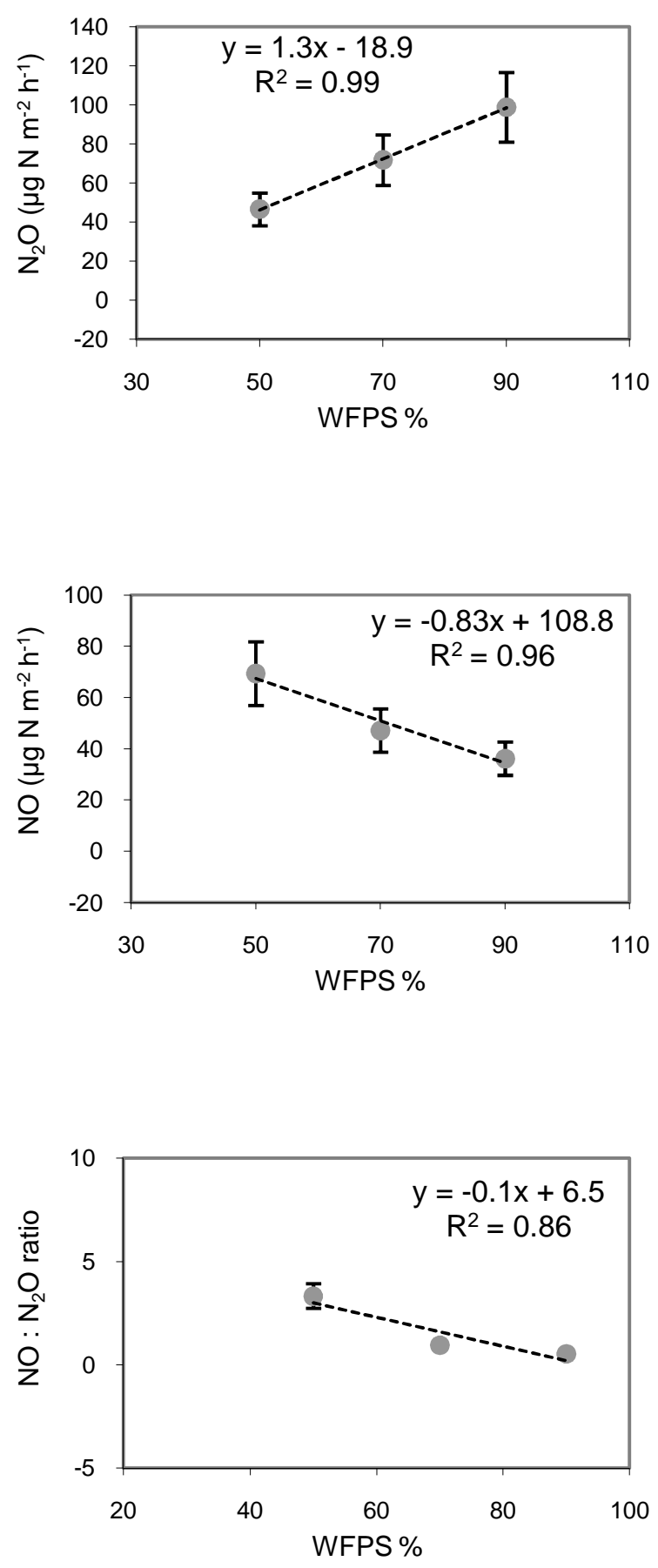

Fig. 3. Correlation of water-filled pore space (WFPS) and $\mathrm{N}_{2} \mathrm{O}$, $\mathrm{NO}$ emission rates and $\mathrm{NO}: \mathrm{N}_{2} \mathrm{O}$ ratio (mean of 31 sites, error bars indicate plus minus standard error).

lithological variation in the forest. Coefficients of variation (CV) ranged between 45 and $72 \%$ for all soil variables except for $\mathrm{pH}(\mathrm{CV}=9 \%)$ and $\mathrm{C}: \mathrm{N}$ ratio $(\mathrm{CV}=11 \%)$.

The $\mathrm{N}_{2} \mathrm{O}$ and $\mathrm{NO}$ emission rates showed a large spatial variation and a highly skewed distribution. Coefficients of variation for the $\mathrm{N}_{2} \mathrm{O}$ emission rates were $133.3,89.9$ and $92.5 \%$, respectively for 50,70 and $90 \%$ WFPS. Coefficients of variation of the NO emission rates for 50,70 and $90 \%$ WFPS were 75.5, 68.8 and $65.2 \%$, respectively. The $\mathrm{N}_{2} \mathrm{O}$ emission rates ranged from 4.5 to $400.5 \mu \mathrm{g} \mathrm{N} \mathrm{m}{ }^{-2} \mathrm{~h}^{-1}$ and the NO emission rates from 6.6 to $265.5 \mu \mathrm{g} \mathrm{N} \mathrm{m}^{-2} \mathrm{~h}^{-1}$. The range and skewness of the $\mathrm{N}_{2} \mathrm{O}$ emission rates was higher than the NO emission rates. The majority of soil samples showed relatively low $\mathrm{N}_{2} \mathrm{O}$ emission rates, with the exception of a few sites (large skewness). Figure 4 shows the spatial variation of the $\mathrm{N}_{2} \mathrm{O}$ and $\mathrm{NO}$ emission rates for the three WFPS levels considered. It also illustrates that measured $\mathrm{N}_{2} \mathrm{O}$ emissions varied substantially over the study region. Compared to $\mathrm{N}_{2} \mathrm{O}$, the spatial variability of $\mathrm{NO}$ emission rates was more or less opposite (Fig. 4).

The NO: $\mathrm{N}_{2} \mathrm{O}$ emission ratio (NO: $\mathrm{N}_{2} \mathrm{O}$ ) varied on average from 3.3 to 0.9 and 0.5 , respectively for 50,70 and $90 \%$ WFPS. The NO: $\mathrm{N}_{2} \mathrm{O}$ ratio showed no marked trend for soil samples taken across the study region (data not shown). Increased moisture levels resulted in a decrease of the measured NO: $\mathrm{N}_{2} \mathrm{O}$ ratio (Fig. 3).

\subsection{Correlation between $\mathrm{N}_{2} \mathrm{O}$ and $\mathrm{NO}$ gas emission rates and soil properties}

For co-variation analysis we only used $\mathrm{N}$ trace gas data at $50 \%$ WFPS, since spatial differences between sampling sites were most pronounced for this treatment. The variation in $\mathrm{N}_{2} \mathrm{O}$ emissions was positively correlated with clay and free iron content and negatively with $\mathrm{pH}$ and silt content (Table 2). No significant correlation was observed for $\mathrm{OC}$ and $\mathrm{TN}$ contents. In contrast, $\mathrm{NO}$ emission rates were significantly positively correlated with $\mathrm{OC}, \mathrm{TN}$ and free iron content and showed a weak significant negative correlation with $\mathrm{C}: \mathrm{N}$ ratio.

These contradictory results could be due to the large variance in $\mathrm{N}_{2} \mathrm{O}$ and $\mathrm{NO}$ emission. Nitrous oxide emission rates for sites at low altitude $(<2000 \mathrm{~m})$ in the western part of the forest (where schists dominate the soilscape) were relatively low (e.g. 8.8-130 $\mu \mathrm{g} \mathrm{N} \mathrm{m}^{-2} \mathrm{~h}^{-1}$ for $50 \%$ WFPS) compared to higher $\mathrm{N}_{2} \mathrm{O}$ emission rates (e.g. up to $238 \mu \mathrm{g} \mathrm{N} \mathrm{m}^{-2} \mathrm{~h}^{-1}$ for $50 \%$ WFPS) for samples taken from higher altitude in the eastern part (where micaschists dominate the soilscape). High NO emissions were distributed among sampling sites with high OC and TN content.

This result indicates that variation in parent material and topography (Fig. 1b, c), which largely control variation in soil properties, exerts a primary control on especially $\mathrm{N}_{2} \mathrm{O}$ emission. Therefore, we separately investigated how correlation between $\mathrm{N}_{2} \mathrm{O}$ and $\mathrm{NO}$ emissions and soil properties varied for low altitude, where schists dominate and high altitude, where micaschists dominate. We did this by creating a different sub dataset according to variation in parent material and altitude: data subset 1: locations at high altitude and micaschists as dominant parent material; and data 

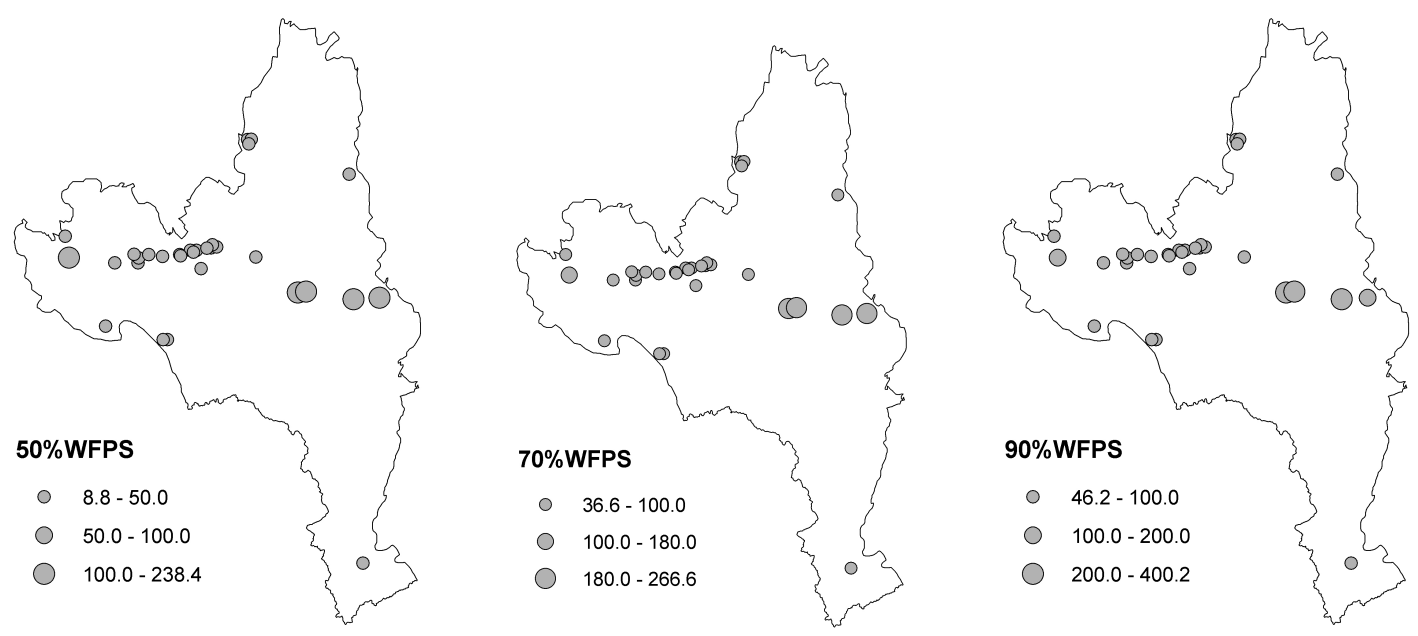

$$
\mathrm{N}_{2} \mathrm{O} \mu \mathrm{g} \mathrm{m}^{-2} \mathrm{~h}^{-1}
$$
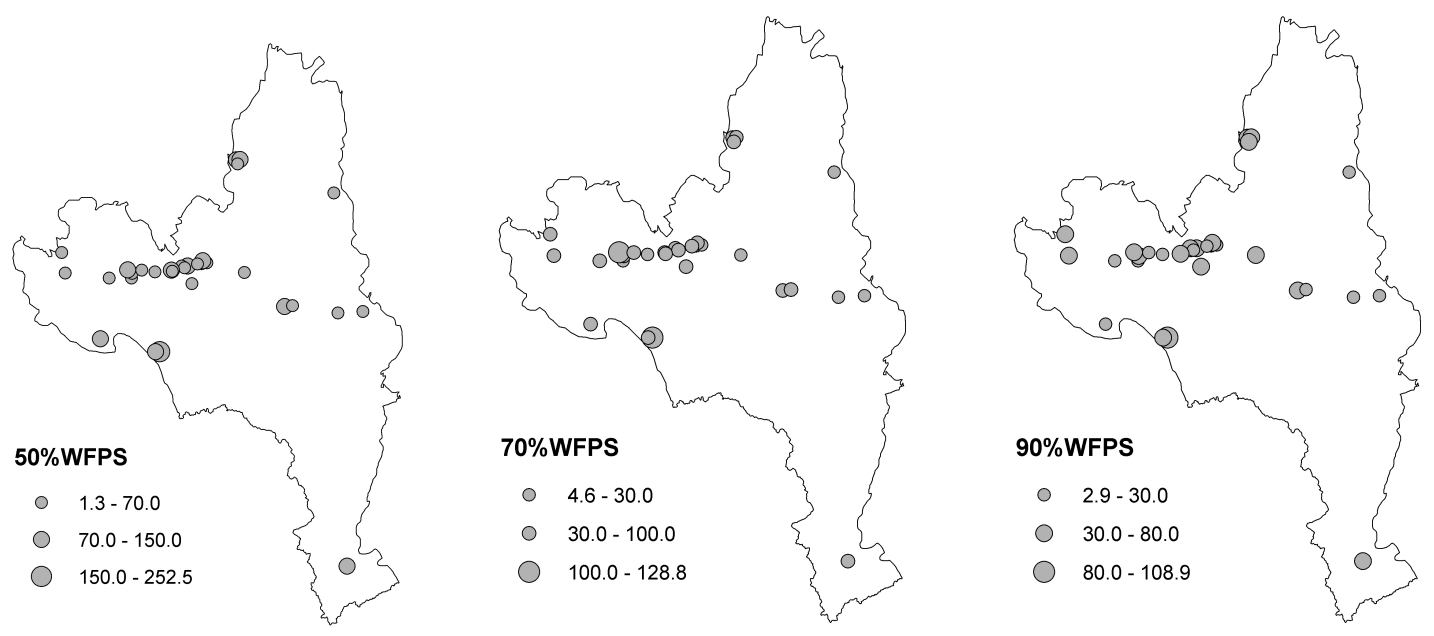

\section{$\mathrm{NO} \mu \mathrm{g} \mathrm{m}^{-2} \mathrm{~h}^{-1}$}

Fig. 4. Spatial distribution of $\mathrm{N}_{2} \mathrm{O}$ (top) and $\mathrm{NO}$ (bottom) emission rates in the Nyungwe forest.

subset 2: locations at low altitude and schists as dominant parent material.

For data subset 1 , the $\mathrm{N}_{2} \mathrm{O}$ emission rate was significantly and positively correlated with $\mathrm{OC}$ and clay content and negatively correlated with $\mathrm{pH}$. The NO emission rate showed significantly negative correlation with $\mathrm{C}: \mathrm{N}$ ratio $(\mathrm{p}<0.05)$ and positive correlation with $\mathrm{OC}$ and TN. Both $\mathrm{N}_{2} \mathrm{O}$ and $\mathrm{NO}$ correlated positively with free iron content but not significant.

For data subset $2, \mathrm{~N}_{2} \mathrm{O}$ emissions were significantly and positively correlated with the OC, TN clay and free iron content. NO emission was positively, significantly correlated with TN and free iron. The correlation was also positive with OC but not significant.

\section{Discussion}

To date, there exist very few coarse-scaled (large area as to exhibit great spatial variability of soil parameters), dataintensive $\mathrm{N}$-oxide flux data for tropical forest ecosystems. However, spatial variability is essential for extrapolation and mechanistic understanding of $\mathrm{N}_{2} \mathrm{O}$ and $\mathrm{NO}$ emission (Breuer et al., 2000; Kiese and Butterbach-Bahl, 2002; Werner et 
Table 2. Correlation coefficients for $\mathrm{N}_{2} \mathrm{O}$ and $\mathrm{NO}$ emission rates and soil properties (silt and clay content; organic carbon (OC), total nitrogen $(\mathrm{TN}), \mathrm{C}: \mathrm{N}$ ratio $\mathrm{pH}$, and free iron (Fe)) for two different data subsets data subset 1: locations at high altitude and micaschists as dominant parent material; and data subset 2: locations at low altitude and schists as dominant parent material. In this analysis we only include $\mathrm{N}$ oxide emission data from the $50 \%$ WFPS; **indicates significant correlations at $P<0.01$ and *indicates significant correlations at $P<0.05$.

\begin{tabular}{|c|c|c|c|c|c|c|c|c|c|}
\hline & & Clay & Silt & Sand & OC & $\mathrm{TN}$ & C:N & $\mathrm{pH}$ & $\mathrm{Fe}$ \\
\hline \multicolumn{10}{|l|}{ Data Subset1 } \\
\hline & $\mathrm{N}_{2} \mathrm{O}$ & $0.59 *$ & -0.57 & 0.07 & $0.68^{*}$ & 0.25 & 0.65 & $-0.77 *$ & 0.26 \\
\hline & NO & 0.19 & 0.58 & -0.56 & $0.61^{*}$ & $0.81^{* *}$ & $-0.63^{*}$ & -0.09 & 0.42 \\
\hline \multicolumn{10}{|l|}{ Data Subset2 } \\
\hline & $\mathrm{N}_{2} \mathrm{O}$ & $0.51 *$ & -0.09 & -0.14 & $0.50^{*}$ & $0.63^{* *}$ & -0.12 & -0.35 & $0.50 *$ \\
\hline & NO & 0.31 & -0.07 & -0.08 & 0.39 & $0.49 *$ & -0.07 & 0.21 & $0.53 *$ \\
\hline \multicolumn{10}{|l|}{ Entire dataset } \\
\hline & $\mathrm{N}_{2} \mathrm{O}$ & $0.58^{*}$ & $-0.52^{*}$ & 0.16 & 0.02 & -0.15 & 0.45 & $-0.59^{* *}$ & $0.38 *$ \\
\hline & $\mathrm{NO}$ & 0.13 & 0.27 & -0.33 & $0.49 * *$ & $0.63^{* *}$ & $-0.36^{*}$ & 0.02 & $0.40 *$ \\
\hline
\end{tabular}

al., 2007b). Understanding spatial $\mathrm{N}$ trace gas emission estimates further requires constrained information of soil and environmental properties. To the best of our knowledge, our $\mathrm{N}_{2} \mathrm{O}$ and $\mathrm{NO}$ flux estimate for 31 different locations in the Nyungwe tropical forest in southwestern Rwanda represent the first large, coarse scale, spatial dataset of $\mathrm{N}_{2} \mathrm{O}$ and $\mathrm{NO}$ emission on the African continent.

The $\mathrm{N}_{2} \mathrm{O}$ emission rates we measured during laboratory incubations were comparable in magnitude with $\mathrm{N}_{2} \mathrm{O}$ fluxes from field measurements at the Kakamega forest sites in Kenya (1.1-324.8 $\mu \mathrm{g} \mathrm{N} \mathrm{m}^{-2} \mathrm{~h}^{-1}$; Werner et al., 2007b). With mean $\mathrm{N}_{2} \mathrm{O}$ emission rates ranging from 46.3 to $98.8 \mu \mathrm{g} \mathrm{N} \mathrm{m}{ }^{-2} \mathrm{~h}^{-1}$ the Nyungwe soil emitted comparable levels of $\mathrm{N}_{2} \mathrm{O}$ as reported by Serca et al. (1994) for the Mayombe forest soils in Democratic Republic of Congo (mean flux in the rainy season: $19.6 \mu \mathrm{g} \mathrm{N} \mathrm{m}^{2} \mathrm{~h}^{-1}$ and mean flux at the end of rainy season: $207 \mu \mathrm{g} \mathrm{N} \mathrm{m}^{2} \mathrm{~h}^{-1}$ ). Furthermore, with an average clay, silt and OC content of $26 \%, 44 \%$ and $4.4 \%$, respectively, the Nyungwe forest soils are similar to the Kakamega (Kenya) rainforest soils (Werner et al., 2007b), (34\% clay, $23 \%$ silt and $3.5 \% \mathrm{C}$ content) and the Mayombe forest soils (1.7-4.5\%C content).

Only Serca et al. (1994) measured NO fluxes from African tropical forest. Their results for the Mayombe forest in DR Congo: $14.4 \mu \mathrm{g} \mathrm{N} \mathrm{m}^{-2} \mathrm{~h}^{-1}$ at the end of a rainy season (mean flux rainy season $4.1 \mu \mathrm{g} \mathrm{N} \mathrm{m}^{-2} \mathrm{~h}^{-1}$ ) were in the lower range of our $\mathrm{NO}$ emissions. In our study we measured individual $\mathrm{N}_{2} \mathrm{O}$ fluxes up to $558.5 \mu \mathrm{g} \mathrm{N} \mathrm{m}^{-2} \mathrm{~h}^{-1}$, which is of similar magnitude as the reported maximum $\mathrm{N}_{2} \mathrm{O}$ fluxes of $324.8 \mu \mathrm{g} \mathrm{N} \mathrm{m}^{-2} \mathrm{~h}^{-1}$ for Kakamega rainforest soils following periods of intensive rainfalls (Werner et al., 2007b). The coefficient of variation between different sampling sites in the Nyungwe for $\mathrm{N}_{2} \mathrm{O}$ emission rates at three WFPS were in good agreement with results from Werner et al. (2007b), who reported values of 52.8-147.9\% for the spatial variation of $\mathrm{N}_{2} \mathrm{O}$ fluxes for the Kakamega forest in Kenya.

Nitrogen trace gas emissions in tropical environments are predominantly governed by WFPS (Davidson, 1991;
Kiese and Butterbach-Bahl, 2002; Werner et al., 2007b). The observed decrease of the NO: $\mathrm{N}_{2} \mathrm{O}$ ratio with increasing WFPS (Fig. 3) indicates that denitrification or nitrifierdenitrification processes was possibly the main pathway of $\mathrm{N}_{2} \mathrm{O}$ gas production rather than nitrification. This assumption is in good agreement with previous observations in rain forest ecosystems in Australia (Kiese and Butterbach-Bahl, 2002; Butterbach-Bahl et al., 2004) and Kenya (Werner et al., 2007b). Based on previous studies, maximum $\mathrm{N}_{2} \mathrm{O}$ emission rates are reported at WFPS values between 50 and $80 \%$, though other studies suggest slightly higher ranges of 60 to $90 \%$ (Davidson, 1991; Kiese and Butterbach-Bahl, 2002; Werner et al., 2007b). In our study maximum $\mathrm{N}_{2} \mathrm{O}$ emission occurred at $90 \%$ WFPS, conditions whereby the denitrification process normally favors $\mathrm{N}_{2}$ formation. The relationship between $\mathrm{N}_{2} \mathrm{O}$ emissions and WFPS was suggested to be linear for Australian rain forest soils (WFPS ranging from 10 to $50 \%$ (Butterbach-Bahl et al., 2004) and exponential for Kakamega rain forest soils in Kenya (WFPS ranging from 40 to $75 \%$ (Werner et al., 2007b)). For our data, using a linear function (Fig. 3), $99 \%$ of the variability of the $\mathrm{N}_{2} \mathrm{O}$ emissions could be explained by changes in soil moisture content. Keller et al. (2005) also found significant relationship between $\mathrm{N}_{2} \mathrm{O}$ emissions and soil moisture for tropical forest site in Brazil.

Maximum NO emissions can be expected at WFPS $<50 \%$ depending on soil physical properties. A quadratic function was reported for the relation between $\mathrm{NO}$ emissions and WFPS for Australian rain forest soils (Butterbach-Bahl et al., 2004) (WFPS levels ranging from $<5 \%$ to $50 \%$ ).

For our data a linear function was able to describe $96 \%$ of the variation between NO emission rates and WFPS (Fig. 3). The NO fluxes at low moisture content $(50 \%$ WFPS) were higher than those at medium (70\% WFPS) and pronounced higher than those at high soil moisture (90\% WFPS). These results are supportive to several other studies which were showing a strong reduction in soil NO 
production if soil moisture is increasing to values $>50 \%$ WFPS (e.g. Butterbach-Bahl et al., 2004).

In contrast to $\mathrm{NO}$ emission, correlation between $\mathrm{N}_{2} \mathrm{O}$ emission and $\mathrm{OC}$ and $\mathrm{TN}$ only appeared in the data subsets. In the western part of the forest, where altitude is lower and schists dominate the soilscape, both OC, but also TN showed a correlation with $\mathrm{N}_{2} \mathrm{O}$ emissions. In the eastern part of the forest (higher altitude and micaschists) both $\mathrm{OC}$ and $\mathrm{TN}$ were correlated with $\mathrm{NO}$ emissions. Further, $\mathrm{pH}$ seems to be an important controlling factor as it appeared in the entire data set and sub-dataset 1 .

Positive correlations of $\mathrm{N}_{2} \mathrm{O}$ emissions with $\mathrm{OC}$ and TN are in agreement with Booth et al. (2005), who showed a direct effect $\mathrm{OC}$ and $\mathrm{TN}$ on $\mathrm{N}_{2} \mathrm{O}$ emission for soils from a wide range of ecosystems. It is well known that low $\mathrm{pH}$ decreases the activity of the $\mathrm{N}_{2} \mathrm{O}$-reductase, thereby increasing production of $\mathrm{N}_{2} \mathrm{O}$ from denitrification (Nömmik, 1956; Weier and Gillam, 1986; Granli and Bockman, 1994). For nitrification, it has also been demonstrated that low $\mathrm{pH}$ values favor $\mathrm{N}_{2} \mathrm{O}$ production (Sitaula and Bakken, 1993; Martikainen and De Boer, 1993; Kesik et al., 2006). Furthermore, it has been shown by Kiese and Butterbach-Bahl (2002) that low $\mathrm{pH}$ was a crucial factor driving high $\mathrm{N}_{2} \mathrm{O}$ emissions from coastal lowland soils in an Australian rainforest.

The importance of soil $\mathrm{N}$ for explaining $\mathrm{N}_{2} \mathrm{O}$ and $\mathrm{NO}$ fluxes may be explained by the fact that nitrogen availability is one of the primary controlling parameters for organic matter mineralization, whereby mineralization is delivering inorganic $\mathrm{N}$ for nitrifying and denitrifying bacteria. Nitrogen content, as an important controlling parameter for $\mathrm{NO}$ emission, was also clearly indicated in the study of Pilegaard et al. (1999) analyzing NO emission rates from temperate forest soils across a wide range of sites in Europe. The negative effect of the $\mathrm{C}: \mathrm{N}$ ratio on the $\mathrm{NO}$ emission rate is similar to that reported by Stark et al. (2002), indicating that the C:N ratio affected the NO emission rate from forest soils of Western North America by controlling $\mathrm{N}$ mineralization.

Breuer et al. (2000), investigating different rain forest sites in tropical Queensland, Australia, reported that nitrate concentration and WFPS content at Kauri Creek; soil pH and nitrate concentration at Lake Eacham; and for all sites $\mathrm{CO}_{2}$ emission, C:N ratio and WFPS content were the most influential factors driving small scale $(<100 \mathrm{~m})$ spatial variations in soil $\mathrm{N}_{2} \mathrm{O}$ emissions. Furthermore, Werner et al. (2007b) explained site differences in $\mathrm{N}_{2} \mathrm{O}$ emissions for different sites in the tropical rainforest of Kakameka, Kenya, by differences in the C:N ratio and clay content. Mapanda et al. (2010) also indicated that variability of $\mathrm{N}_{2} \mathrm{O}$ emissions from Miombo woodland in Zimbabwe is controlled by changes of soil moisture, mineral $\mathrm{N}$ and $\mathrm{pH}$. Further, a recent study by Wolf et al. (2011) show that increment of tree basal area can be promising proxy to predict soil $\mathrm{N}$-oxide fluxes in nitrogen limited tropical montane forest in southern Ecuador. It must be pointed out that the latter results of $\mathrm{N}_{2} \mathrm{O}$ and $\mathrm{NO}$ emissions from tropical rain forest were field measurements at a small scale, while we analyzed the spatial variability of incubation fluxes along an approx. $40 \mathrm{~km}$ long transect with 31 sampling sites and resulted in high coefficient of variation for both $\mathrm{N}_{2} \mathrm{O}$ and $\mathrm{NO}$ emissions.

The acidic soils of the Nyungwe forest in combination with high free iron contents could favor chemodenitrification (auto-decomposition of nitrites) for NO and $\mathrm{N}_{2} \mathrm{O}$ production in addition to microbial processes (Van Cleemput and Baert, 1984). All the favorable conditions for this phenomenon to occur are present: very low $\mathrm{pH}$, abundance of clay and reduced metals (e.g. $\mathrm{Fe}^{2+}$ ) (Nelson and Bremner, 1970; Wullstein and Gilmour, 1964). Positive correlations of $\mathrm{N}_{2} \mathrm{O}$ and $\mathrm{NO}$ emissions with clay content (for both data subsets) and free iron for the entire data and data subsets and negative correlations with soil $\mathrm{pH}\left(\mathrm{N}_{2} \mathrm{O}\right.$ only) (Table 2) give further supporting evidence that chemodenitrification might play a role. Serca et al. (1994) also found that chemo-denitrification in acid Mayombe forest soils is a potentially important cause of $\mathrm{N}$ oxide gases production. Again, variation in parent material and topography caused average free iron content $(4.1 \pm 0.2 \%)$ to be higher in the eastern part of the forest, where micaschists dominate the soilscape, than the average free iron content $(2.5 \pm 0.2 \%$ free iron) at western part, where chists dominate the soilscape.

Of course, our incubation study cannot unambiguously improve $\mathrm{N}$ trace gas source strength estimates for tropical forests since all results are based on incubations for a few days only. Nonetheless, our study reveals clear aspects of spatial variability and control of $\mathrm{N}_{2} \mathrm{O}$ and $\mathrm{NO}$ emissions that may assist to the development of baseline information required for reducing emissions from deforestation and degradation activities designed to limit greenhouse gas emissions from tropical forests from developing countries ((UN-REDD program, Stickler et al., 2009). Finally, an additional benefit of the obtained results is their potential to validate the mechanistic biogeochemical (e.g. ForestDNDC-tropica, Werner et al., 2007a)) models and close gaps in global trace gas budgets.

\section{Conclusions}

This laboratory study provided a unique and large spatial explicit data set of $\mathrm{N}_{2} \mathrm{O}$ and $\mathrm{NO}$ fluxes for tropical rain forest soils. Nitrous oxide and $\mathrm{NO}$ emissions rates were in the range with those reported for African tropical rain forests, but showed a large spatial variation. Soil water content was found to affect $\mathrm{NO}$ and $\mathrm{N}_{2} \mathrm{O}$ emission differently. The relationship between soil properties and $\mathrm{N}_{2} \mathrm{O}$ and $\mathrm{NO}$ emission rates was somewhat scale-dependent and spatial information on topography and parent material distribution helped to determine biochemical (OC, TN) and geological $\left(\mathrm{pH}\right.$, free iron) controls on $\mathrm{N}_{2} \mathrm{O}$ and $\mathrm{NO}$ emission. Positive correlations with soil carbon and nitrogen 
indicate a biological control over $\mathrm{N}_{2} \mathrm{O}$ and $\mathrm{NO}$ production. But, a negative correlation (only $\mathrm{N}_{2} \mathrm{O}$ ) with soil $\mathrm{pH}$ and a positive correlation with free iron and clay content suggest that chemo-denitrification might be an important alternative production pathway. It would be interesting and useful to define and distinguish chemo-denitrification from related pathway processes in acidic soils of the Nyungwe forest. $\mathrm{We}$, therefore, recommend that future research on $\mathrm{N}$ trace gas research in tropical forests include efforts to differentiate biological and chemical pathways for $\mathrm{N}$ trace gas emission.

Edited by: E. Nemitz

\section{References}

Allen, T.: Particle size measurement, London, Chapman and Hall, 1975.

Bai, E. and Houlton, B. Z.: Coupled isotopic and process-based modeling of gaseous nitrogen losses from, Global Biogeochem. Cy., 23, GB2011, doi:10.1029/2008GB003361, 2009.

Breuer, L., Papen, H., and Butterbach-Bahl, K.: $\mathrm{N}_{2} \mathrm{O}$ emission from tropical forest soils of Australia, J. Geophys. Res., 105, 2635326368, doi:10.1029/2000JD900424, 2000.

Booth, M. S, Stark, J. M., and Rastetter, E.: Controls on nitrogen cycling in terrestrial ecosystems: a synthetic analysis of literature data, Ecol. Monogr., 75, 139-157, doi:10.1890/04-0988, 2005.

Bouwman, A. F., Fung, I., Matthews, E., and John, J.: Global analysis of the potential for $\mathrm{N}_{2} \mathrm{O}$ production in natural soils, Global Biogeochem. Cy, 7, 557-597, doi:10.1029/93GB01186, 1993.

Butterbach-Bahl, K., Kock, M., Willibald, G., Hewett, B., Buhagiar, S., Papen, H., and Kiese, R.: Temporal variations of fluxes of $\mathrm{NO}, \mathrm{NO}_{2}, \mathrm{~N}_{2} \mathrm{O}, \mathrm{CO}_{2}$, and $\mathrm{CH}_{4}$ in a tropical rain forest ecosystem, Global Biogeochem. Cy., 18, GB3012, doi:10.1029/2004GB002243, 2004.

Crutzen, P. J.: The role of $\mathrm{NO}$ and $\mathrm{NO}_{2}$ in the chemistry of the troposphere and stratosphere, Annu. Rev. Earth Planet. Sci., 7, 443-472, doi:10.1146/annurev.ea.07.050179.002303, 1979.

Davidson, E. A.: Fluxes of nitrous oxide and nitric oxide from terrestrial ecosystems, in: Microbial Production and Consumption of Greenhouse Gases: Methane, Nitrogen Oxides and Halomethanes, edited by: Rogers, J. and Whitman, W., American Society for Microbiology, Washington D.C., USA, 219-235, 1991.

Davidson, E. A. and Kingerlee, W.: A global inventory of nitric oxide emissions from soils, Nutr. Cycl. Agroecosyst., 48, 37-50, doi:10.1023/A:1009738715891, 1997.

Davidson, E. A., Matson, P. A., Vitousek, P. M., Riley, R., Dunkin, K., Garcia-Me'ndez, G., and Maass, J. M.: Processes regulating soil emissions of $\mathrm{NO}$ and $\mathrm{N}_{2} \mathrm{O}$ in a seasonally dry tropical forest, Ecology, 74, 130-139, doi:10.2307/1939508, 1993.

Davidson, E. A., Keller, M., Ericson, H. E., and Vetchot, L. V.: Testing a conceptual model of soil emission of nitrous and nitric oxides, Bioscience, 50, 667-680, doi:10.1641/00063568(2000)050[0667:TACMOS]2.0.CO;2, 2000.

Defries, R., Rudel, T., Uriarte, M., and Hansen, M.: Deforestation driven by urban population growth and agricultural trade in the twenty-first century, Nat. Geosci., 3, 178-181, doi:10.1038/NGEO756, 2010.

Delmas, R., Serca, D., and Jambert, C.: Global inventory of NOx sources, Nutrient cycling in agroecosystems, 48, 51-60, doi:10.1023/A:1009793806086, 1997.

Fischer, E. and Killmann, D.: Illustrated field guide to the plant of Nyungwe National Park Rwanda, Koblenz Geographical Colloquia Series Biogeographical Monographs, 1, Germany, 2008.

Graham, C., Moermond, T. C., Kristensen, K. A., and Mvukiyumwami, J.: Seed dispersal effectivness by two Bulbuls on Maesa lanceolata, an African montane forest tree, Biotropica., 27, 479-486, 1995.

Granli, T. and Bockman, O. C.: soil water content, nitrous Oxide from Agriculture, Norw. J. agric. Sci., 12, 34-42, 1994.

Gut, A., Neftel, A., Staffelbach, T., Riedo, M., and Lehmann, B. E.: Nitric oxide flux from soil during the growing season of wheat by continuous measurements of the NO soil-atmosphere concentration gradient: A process study, Plant and soil, 216, 165-180 doi:10.1023/A:1004752104808, 1999.

Gut, A., van Dijk, S. M., Scheibe, M., Rummel, U., Welling, M., Ammann, C., Meixner, F. X., Kirkman, G. A., Andreae, M. O., and Lehmann, B. E.: NO emission from an Amazonian rain forest soil: Continuous measurements of NO flux and soil concentration, J. Geophys. Res., 107, 8057, doi:10.1029/2001JD000521, 2002.

Holland, E. A. and Lamerqur, J. F.: Modeling bio-atmospheric coupling of the nitrogen cycle though NOx emission and NOy deposition, Nutr. Cycl. Agroecosys., 48, 7-24, doi:10.1023/A:1009710122179, 1997.

Ishizuka, S., Iswandi, A., Nakajima, Y., Yonemura, S., Sudo, S., Tsuruta, H., and Muriyarso, D.: Spatial patterns of greenhouse gas emission in a tropical rainforest in Indonesia, Nutr. Cycl. Agroecosyst., 71, 55-62, doi:10.1007/s10705-004-5284-7, 2005.

Keller, M. and Reiners, W. A.: Soil-atmosphere exchange of nitrous oxide, nitric oxide, and methane under secondary secession of pasture to forest in the Atlantic lowlands of Costa Rica, Global Biogeochem. Cy., 8, 399-409, doi:10.1029/94GB01660, 1994.

Keller, M., Varner, R., Dias, J. D., Silva, H., Crill, P., De Oliveira, R. C., and Asner, G. P.: Soil-atmosphere exchange of nitrous oxide, methane, and carbon dioxide in logged and undisturbed forest in the Tapajos National Forest, Brazil, Earth Inter., 9, 1-27, 2005.

Kesik, M., Blagodatsky, S., Papen, H., and Butterbach-Bahl, K.: Effect of $\mathrm{pH}$, temperature and substrate on $\mathrm{N}_{2} \mathrm{O}$, $\mathrm{NO}$ and $\mathrm{CO}_{2}$ production by Alcaligenes faecalis p, J. Appl, Microbiol, 101, 655-667, doi:10.1111/j.1365-2672.2006.02927.x, 2006.

Kiese, R. and Butterbach-Bahl, K.: $\mathrm{N}_{2} \mathrm{O}$ and $\mathrm{CO}_{2}$ emissions from three different tropical forest sites in the Wet Tropics of Queensland, Australia, Soil Biol. Biochem., 34, 975-987, doi:10.1016/S0038-0717(02)00031-7, 2002.

Kiese, R., Hewett, B., Graham, A., and Butterbach-Bahl, K.: Seasonal variability of $\mathrm{N}_{2} \mathrm{O}$ emissions and $\mathrm{CH} 4$ uptake by tropical rainforest soils of Queensland, Australia, Global Biogeochem. Cy., 17, 1043, doi:10.1029/2002GB002014, 2003.

Kiese, R., Li, C., Hilbert, D. W., Papen, H., and ButterbachBahl, K.: Regional application of PnET-N-DNDC for estimating the $\mathrm{N}_{2} \mathrm{O}$ source strength of tropical rainforests in the Wet Tropics of Australia, Global Change Biol., 11, 128-144, doi:10.1111/j.1365-2486.2004.00873.x, 2005. 
Kroeze, C., Mozier, A., and Bouwman, L.: Closing the $\mathrm{N}_{2} \mathrm{O}$ Budget: A retrospective analysis, Global Biogeochem. Cy., 13, 1-8, doi:10.1029/1998GB900020, 1999.

Ludwig, J., Meixner, F. X., Vogel, B., and Forstner, J.: Soil-air exchange of nitric oxide: An overview of processes, environmental factors, and modeling studies, Biogeochemistry, 52, 225-257, doi:10.1023/A:1006424330555, 2001.

Mapanda, F., Mupini, J., Wuta , M., Nyamangara, J., and Ree, R. M.: A cross-ecosystem assessment of the effects of land cover and land use on soil emission of selected greenhouse gases and related soil properties in Zimbabwe, Eur. J. Soil Sci., 61, 721733, doi:10.1111/j.1365-2389.2010.01266.x, 2010.

Martikainen, P. J. and De Boer, W.: Nitrous oxide production and nitrification in acidic soil from a Dutch coniferous forest, Soil Biol. Biochem., 25, 343-347, doi:10.1016/00380717(93)90133-V, 1993.

Masozera, M. K. and Alavalapati, J. R. R.: Forest dependency and its implicatios for protected areas management: a case study from the Nyungwe forest reserve, Rwanda, Scand. J. For. Res., 19, 85-92, 2004.

Matson, P. A. and Vitousek, P. M.: Ecosystem approach to a global nitrous oxide budget, Bioscience, 40, 667-671, doi:10.2307/1311434, 1990.

Meehl, G. A., Stocker, T. F., Collins, W. D., Friedlingstein, P., Gaye, A. T., Gregory, J. M., Kitoh, A., Knutti, R., Murphy, J. M., Noda, A., Raper, S. C. B., Watterson, I. G., Weaver, A. J., and Zhao, Z. C.: Global climate projections, in: Climate Change 2007: The Physical Basis, edited by: Solomon, S., Qin, D., Manning, M., Chen, Z., Marquis, M., Averyt, K. B., Tignor, M., and Miller, H. L., Contribution of Working Group I to Fourth Assessment Report of IPCC on Climate Change, Cambridge University Press, Cambridge, UK/NY, USA, 2007.

Mehra, O. P. and Jackson, M. L.: Iron oxide removal from soils and clays by a dithionite-citrate system buffered with sodium bicarbonate, Clay Clay Min., 7, 317-327, 1960.

Minagri et CTB/BTS.: Interprétation des données climatiques du Rwanda d'après Papadakis. Période 1974-1989. Volume 1 : température et humidité relative extrapolées. Carte Pédologique du Rwanda. Ministère de l'Agriculture et de l'Elevage et Coopération Technique Belge, Kigali, Rwanda, 1993a.

Minagri et CTB/BTS.: Interprétation des données climatiques du Rwanda d'après Papadakis. Période 1974-1989. Volume 1: température et humidité relative originales. Carte Pédologique du Rwanda. Ministère de l'Agriculture et de l'Elevage et Coopération Technique Belge, Kigali, Rwanda, 1993b.

Mosier, A., Kroeze, C., Nevison, C., Oenema, C., Seitzinger, S., and Van Cleemput, O.: Closing the global $\mathrm{N}_{2} \mathrm{O}$ budget: nitrous oxide emissions through the agricultural nitrogen cycle OECD/IPCC/IEA phase II development of IPCC guidelines for national greenhouse gas inventory methodology, Nutr. Cycl. Agroecosys., 52, 225-248, doi:10.1023/A:1009740530221, 1998.

Nelson, D. W. and Bremner, J. M.: Gaseous product of nitrite decomposition in soils, Soil Biol. Biochem., 2, 203-215, 1970.

Nsabimana, D.: Carbon stock and fluxes in Nyungwe forest and Ruhande Arboretum in Rwanda, Ph.D. thesis, Gothenburg University, Sweden, 2009.

Nömmik, H.: Investigations on denitrification in soils, Acta Agr. Scand., 195-228, 1956.
Otter, L. B., Yang, W. X., Scholes, M. C., and Meixner, F. X.: Nitric oxide emissions from a Southern African savanna, Geophys. Res., 104, 18471-18485, doi:10.1029/1999JD900148, 1999.

Pilegaard, K., Hummelshoj, P., and Jensen, N. O.: Nitric oxide emission from a Norway spruce forest floor, Geophys. Res., 104, 3433-3445, doi:10.1029/1998JD100050, 1999.

Plumptre, A. J., Davenport, T. R. B., Behanyana, M., Kityo, R., Eilu, G., Ssegawa, P., Ewango, C., Meirte, D., Kahindo, C., Herremans, M., Peterhans, J. K., Pilgrim, J. D., Wilson, M., Languy, M., and Moyer, D.: The biodiversity of the Albertine Rift, Biol. Conserv., 134, 178-194, doi:10.1016/j.biocon.2006.08.021, 2007.

Prather, M. and Ehhalt, D.: Atmospheric chemistry and greenhouse gases, in: Climate Change: The Scientific Basis, Contribution of Working Group I to the Third Assessment Report of the Intergovernmental Panel on Climate Change, edited by: Joos, F. and McFarlan, M., Cambridge Univ. Press, New York, 2001.

Serca, D., Delmas, R., Jambert, C., and Labroue, L.: Emissions of nitrogen oxides from equatorial rainforests in central Africa - origin and regulation of NO emissions from soils, Tellus, Ser. B., 46, 243-254, doi:10.1034/j.1600-0889.1994.t01-3-00001.x, 1994.

Sitaula, B. K. and Bakken, L. R.: Nitrous oxide release from spruce forest soil: relationship with nitrification, methane uptake, temperature, moisture and fertilization, Soil Biol. Biochem., 25, 1415-1421, doi:10.1016/0038-0717(93)90056-H, 1993.

Stark, L. M., Smart, D. R., Hart, S. C., and Haubensak, K. A.: Regulation of nitric oxide emission from forest and rangeland soils of Western North America. Ecology, 83, 2278-2292, doi:10.2307/3072059, 2002.

SPSS Inc.: SPSS 16.0 Base User's Guide, Chicago, IL, SPSS Inc, 2007.

Stickler, C., Nepstad, D. C., Coe, M. T., Mcgrath, D. G., Rodrigues, H. O., Walker, W. S., Soares-Filho, B. S., and Davidon, E. A.: The potential ecological cost and cobenefits of REDD: a critical review and case study from the Amazon region, Glob. Change Biol., 15, 2803-2824, doi:10.1111/j.1365-2486.2009.02109.x, 2009.

Sun, C., Kaplin, B. A., Kristensen, K. A., Munyaligoga, V., Mvukiyumwami, J., Kajondo, K. K., and Moermond, T. C.: Tree phenology in a tropical montane forest in Rwanda, Biotropica., 28, 668-681, 1996.

UGent/MINAGRI.: Carte Pédologique de RWESERO, feuille 29. Réalisée dans le cadre du projet "Carte Pédologique du Rwanda" (AGCD, CTB) et finalisée au Laboratoire de Pédologie - UGent (Ed.: E. Van Ranst), avec la collaboration de l' UCL, Gand. ISBN-10: 90-76769-29-X, 2000a.

UGent/MINAGRI.: Carte Pédologique de MUSHUBI, feuille 30. Réalisée dans le cadre du projet "Carte Pédologique du Rwanda" (AGCD, CTB) et finalisée au Laboratoire de Pédologie - UGent (Ed.: E. Van Ranst), avec la collaboration de l' UCL, Gand. ISBN-10: 90-76769-30-3, 2000b.

UGent/MINAGRI.: Carte Pédologique de BUGUMYA, feuille 38. Réalisée dans le cadre du projet "Carte Pédologique du Rwanda" (AGCD, CTB) et finalisée au Laboratoire de Pédologie - UGent (Ed.: E. Van Ranst), avec la collaboration de l' UCL, Gand. ISBN-10: 90-76769-38-9, 2000c.

UGent/MINAGRI.: Carte Pédologique de NSHILI, feuille 39. Réalisée dans le cadre du projet "Carte Pédologique du Rwanda" 
(AGCD, CTB) et finalisée au Laboratoire de Pédologie - UGent (Ed.: E. Van Ranst), avec la collaboration de l' UCL, Gand. ISBN-10: 90-76769-39-7, 2000d.

Van Cleemput, O. and Baert, L.: Nitrite: a key compound in $\mathrm{N}$ loss processes and acid conditions, Plant Soil, 76, 233-241, doi:10.1007/BF02205583, 1984.

Van Dijk, M. S., Gut, A., Kirkman, A. G., Meixner, F. X., and Andreae, O. M.: Biogenic NO emissions from forest and pasture soils: Relating laboratory studies to field measurements, Geophys. Res., 107, 8058, doi:10.1029/2001JD000358, 2002.

Van Haren, J. L. M., De Oliveira, R. C., Restrepo-Coupe, N., Hutyra, L., De Camargo, P. B., Keller, M., and Saleska, S. R.: Do plant species influence soil $\mathrm{CO}_{2}$ and $\mathrm{N}_{2} \mathrm{O}$ fluxes in a diverse tropical forest?, J. Geophys. Res., 115, G03010, doi:10.1029/2009JG001231, 2010.

Verchot, L. V., Davidson, E. A., Cattânio, J. H., Ackerman, I. L., Erickson, H. E., and Keller, M.: Land use change and biogeochemical controls of nitrogen oxide emissions from soils in eastern Amazonia, Global Biogeochem. Cy., 13, 31-46, doi:10.1029/1998GB900019, 1999.

Weier, K. L. and Gillam, J. W.: Effect of acidity on nitrogen mineralization and nitrification in Atlantic Coastal Plain soils, Soil Sci. Soc. Am. J., 50, 1210-1214, 1986.

Werner, C., Zheng, X., Tang, J., Xie, B., Liu, C., Kiese, R., and Butterbach-Bahl, K.: $\mathrm{N}_{2} \mathrm{O}, \mathrm{CH}_{4}$, and $\mathrm{CO}_{2}$ emission from seasonl tropical rainforests and a rubber plantation in southwest China, Plant Soil, 289, 335-353, doi:10.1007/s11104-006-9143y, 2006.
Werner, C., Butterbach-Bahl, K., Haas, E., Hickler, T., and Kiese, R.: A global inventory of $\mathrm{N}_{2} \mathrm{O}$ emissions from tropical rainforest soils using a detailed biogeochemical model, Global Biogeochem. Cy., 21, GB3010, doi:10.1029/2006GB002909, 2007a.

Werner, C., Kiese, R., and Butterbach-Bahl, K.: Soil-atmosphere exchange of $\mathrm{N}_{2} \mathrm{O}, \mathrm{CH}_{4}$, and $\mathrm{CO}_{2}$ and controlling environmental factors for tropical rain forest sites in western Kenya, Geophys. Res., 112, D03308, doi:10.1029/2006JD007388, 2007b.

Wolf, K., Veldkamp, E., Homeier, J., and Martinson, G. O.: Nitrogen availability lonks forest productivity, soil nitrous oxide and nitric oxide fluxes of a tropical montane forest in southern Ecuador, Global Biogeochem. Cy., 25, GB4009, doi:10.1029/2010GB003876, 2011.

WMO.: The state of greenhouse gases in the atmosphere using global observations up to December 2004, World Meteorological Organization, Greenhouse Gas bull, 1, Geneva, Switzerland, 2006.

Wullstein, L. H. and Gimour, C. M.: Non-enzymatic gaseous loss of nitrite from clay and soil system, Soil. Sci., 97, 428-430, 1964. 